\title{
Febrile Neutropenia following Parvovirus B19 Infection and Cross Anti-Kell Reaction to E. Coli in Pregnancy
}

\section{Infeção por parvovírus B19 causando neutropenia febril e reação cruzada anti-Kell com $E$. coli na gravidez}

\author{
Pedro Brandão ${ }^{1,2}$ Marília Freixo $^{1} \quad$ Elisa Soares $^{1}$ Catarina Estevinho ${ }^{1}$ Ana Sofia Portela Carvalho ${ }^{1}$ \\ Anabela Melo ${ }^{1}$ \\ ${ }^{1}$ Department of Obstetrics and Gynecology, Centro Hospitalar \\ Tâmega e Sousa, Porto, Portugal \\ 2 Faculty of Medicine, Universidade do Porto, Porto, Portugal \\ Address for correspondence Pedro Brandão, Avenida do Hospital \\ Padre Américo 210, 4564-007, Penafiel, Porto, Portugal \\ (e-mail: pedrobrandaoleite@gmail.com).
}

Rev Bras Ginecol Obstet 2018;40:372-376.

\section{Abstract \\ Keywords \\ - coombs test \\ - escherichia coli \\ - kell-active proteins \\ - parvovirus antenatal infection \\ - pregnancy complications \\ - infections}

\section{Resumo}

Parvovirus B19 has tropism for red line blood cells, causing immune hydrops during pregnancy. A positive anti-Kell Coombs reaction usually happens during pregnancy when there is production of antibodies that target Kell antigens, but cross reactions to other antigens may occur. A 24-year-old Gypsy primigravida, 0 Rhesus positive, presented with persistent isolated hyperthermia for 2 weeks and a positive indirect Coombs test result with anti-Kell antibodies at routine tests. She had a 19-week live fetus. The blood tests revealed bicytopenia with iron deficiency anemia, leucopoenia with neutropenia, and elevated C-reactive protein. She was medicated with imipenem, and had a slow clinical recovery. Blood, urine and sputum samples were taken to perform cultures and to exclude other systemic infections. Escherichia coli was isolated in the urine, which most probably caused a transient cross anti-Kell reaction. Haemophilus influenza in the sputum and seroconversion to parvovirus B19 was confirmed, causing unusual deficits in the white cells, culminating in febrile neutropenia. Despite the patient's lack of compliance to the medical care, both maternal and fetal/neonatal outcomes were good. This a rare case report of 2 rare phenomena, a cross anti-Kell reaction to $E$. coli and parvovirus B19 infection with tropism for white cells causing febrile neutropenia, both events occurring simultaneously during pregnancy.

O parvovírus B19 tem tropismo para as células sanguíneas da linha vermelha, causando hidropsia imune durante a gravidez. O teste Coombs anti-Kell positivo ocorre durante a gravidez quando há produção de anticorpos contra os antígenos de Kell, mas pode haver reações cruzadas para outros antígenos. Uma grávida primigesta de etnia cigana, de 24 anos, 0 Rhesus positivo, recorreu ao hospital às 19 semanas de gestação por hipertermia isolada persistente por 2 semanas e um teste Coombs indireto positivo por anticorpos anti-Kell em testes de rotina da gravidez. O estudo analítico revelou received

December 2, 2017

accepted

April 16, 2018

published online

June 20, 2018
DOI https://doi.org/

$10.1055 / \mathrm{s}-0038-1657787$ ISSN 0100-7203.
Copyright $\odot 2018$ by Thieme Revinter

Publicações Ltda, Rio de Janeiro, Brazil

License terms

(c) $(1) \$$ 
Palavras-chave

- teste coombs

- escherichia coli

- proteínas kellativas

- infeção antenatal por parvovírus

- complicações na gravidez

- infecções bicitopenia com anemia ferropênica, leucopenia com neutropenia, e elevação da proteína C-reativa. A paciente foi medicada com imipenem, e teve uma recuperação clínica lenta. Foram colhidas amostras de sangue, urina e expectoração para culturas bacterianas. Na urina, foi isolada Escherichia coli, o que provavelmente causou a reação anti-Kell cruzada transitória. Na expectoração, foi isolada Haemophilus influenza, e foi confirmada seroconversão para o parvovírus B19, que causou um déficit incomum na linhagem sanguínea branca, culminando com neutropenia febril. Apesar da má adesão aos cuidados médicos, os desfechos materno e fetal/neonatal foram bons. Este é um caso de 2 fenômenos raros, uma reação cruzada anti-Kell à infecção por $E$. coli, e parvovírus B19 com tropismo para células brancas causando neutropenia febril, ambos ocorrendo simultaneamente durante a gravidez.

\section{Introduction}

Pregnancy is a physiological state of immunosuppression. This raises the risk of asymptomatic colonizations or clinical infections. Concerning infections during pregnancy, there is a general trend to overvalue their teratogenic effect, especially regarding infections caused by toxoplasma, other viruses (syphilis, varicella-zoster, parvovirus B19), rubella, cytomegalovirus and herpes (TORCH) agents, and sometimes the potential harm to the mother is underestimated. ${ }^{1}$ As immune-compromised patients, pregnant women are not only prone to contracting more infections, but also more severe infections, with challenging differential diagnoses (including the physiological changes that occur during pregnancy), and that are usually harder to treat, requiring inpatient care and intravenous medication more frequently.

Parvovirus B19 is a frequent and highly infectious virus during childhood, and is the cause of the fifth disease, also called erythema infectiosum or "slapped cheek syndrome", because of the characteristic facial rash. In healthy adults, it may cause a self-limited febrile illness with mild unspecific symptoms such as hyperthermia, arthralgia or erythema. ${ }^{2}$ This fact may make it hard to suspect if there is no history of contact with affected people. The disease may be diagnosed with serologic tests (demonstrating seroconversion) or a polymerase chain reaction (PCR) test for viral DNA. ${ }^{3}$ The virus has tropism for erythrocytes, so it may cause transient aplasia of the red line. ${ }^{4}$ The affection of white cells and platelets is quite rare. ${ }^{5,6}$ There is no specific treatment, as is the case for most temporary viral diseases. ${ }^{7}$ The infection by parvovirus B19 is also a well-known potentially teratogenic infection if acquired during pregnancy, especially before the 20th week of gestation, and thus the importance of the diagnosis during pregnancy. The most common effect is hidropsia fetalis due to severe fetal anemia caused by the virus' tropism for the erythrocytes. Parvovirus B19 infection may also cause fetal myocarditis due to infection of the myocytes, which are attracted by the $P$ antigen expressed on the fetal cardiac cells, leading to cardiac failure, abortion and/or fetal death. ${ }^{8-10}$ The obstetric ultrasound is of upmost value to evaluate fetal morphology, presence of fetal edema, amniotic fluid index (AFI), and middle cerebral artery systol- ic peak velocity, which, if above 1.5 multiples of the median (MoM), may be an indirect sign of fetal anemia. This may be confirmed by culdocentesis. $^{2}$

Pregnancy itself may induce changes in the blood cell count, a slight tendency to mild anemia, thrombocytopenia and leukocytosis, which are considered physiological changes. ${ }^{11}$ Although more uncommon, other findings in blood tests during pregnancy are those concerning the indirect Coombs test, revealing some degree of cross reaction to fetal red cell antigens. The most common reaction (in the absence of prophylaxis) is in the Rhesus (Rh) antigens in Rh negative mothers. Minor antigens are common and less concerning, such as the Kell antigen. ${ }^{12}$ Kell antigen is highly immunogenic, but more than $90 \%$ of the population is Kellnegative; therefore Kell is not as usually associated with incompatibility as Rhesus. As for other immunogenic reactions, there may be cross reactions to similar antigens. There are some old studies that report that some microorganisms (gram-negative bacteria) may contain antigens similar to or cross-reactive with human blood group antigens. Some subtypes of Escherichia coli may produce soluble substances with A-like and K-like blood group activity; however, little has been described in the literature about this phenomenon so far. ${ }^{13,14}$

\section{Case Description}

A 24-year-old pregnant gypsy woman came to our emergency department with persistent hyperthermia during the previous 2 weeks (around $39^{\circ} \mathrm{C}$ ).

She was at the 19th week of her 1st gestation, estimated by the 1 st ultrasound scan, which was performed at 16 weeks. This pregnancy had been poorly monitored because of the patient's lack of compliance. She had no medical history of any other surgical pathologic background, and no history of transfusion of blood components. She was immune to toxoplasmosis and rubella, and her blood type was $0 \mathrm{Rh}$ positive.

The patient presented with hyperthermia persisting for 2 weeks. She had been previously medicated by her general practitioner (GP) with paracetamol $1 \mathrm{~g}$ per os, with temporary symptomatic relief. She reported her youngest nephew 
(whom she usually took care of) had had varicella zoster primary infection (chickenpox) three weeks before, but she didn't know if she had had this infection before, and she hadn't been medicated with immunoglobulin. The patient didn't have any other signs or symptoms, including those concerning the respiratory, digestive or urinary tracts, or any cutaneous erythema. She also had the result of her routine pregnancy blood tests performed during this 2-week period, which showed a positive indirect Coombs test with anti-Kell antibodies (the titter was 1:32).

Upon admission, she had $38^{\circ} \mathrm{C}$ of body (auricular) temperature, $110 / 58 \mathrm{~mm} \mathrm{Hg}$ of blood pressure, $112 \mathrm{bpm}$ of cardiac frequency, 16 breaths per minute, and $98 \%$ of peripheral blood 02 saturation. She had normal mucosa coloration, and underwent cardiac and pulmonary auscultations, as well as an abdominal examination. There were no signs of edema. There were no abnormal cutaneous findings. The patient refused the gynecological examination.

The obstetric ultrasound scan revealed the patient had a 19-week live fetus, with no abnormal morphologic findings and normal AFI.

Maternal blood tests revealed bicytopenia with iron deficiency anemia (hemoglobin [Hgb]: 9.1 g/dL; mean corpuscular hemoglobin: 26.8\%; mean corpuscular volume: $79 \mathrm{fL}$; iron: $34 \mathrm{ug} / \mathrm{dL}$; and transferrin saturation [TSAT]: 10\%), leukopenia $(1700 / \mathrm{uL})$ with neutropenia (200/uL, 13.6\%), and elevated C-reactive protein (CRP: $163 \mathrm{mg} / \mathrm{L}$ ). Blood, urine and sputum samples were taken to perform cultures and to exclude infection by: the hepatitis B virus (HBV) or the hepatitis $C$ virus (HCV), the human immunodeficiency virus (HIV), cytomegalovirus (CMV), the Epstein-Barr virus (EBV), parvovirus B19, brucellosis, tuberculosis and syphilis. The Coombs test was repeated.

With the presumptive diagnosis of febrile neutropenia of unknown etiology, the patient was admitted to our high-risk pregnancy ward in isolation for treatment and further investigation. Empiric treatment with intravenous imipenem (500 mg each 12 hours) was started.

During the first days, the patient maintained the hyperthermia despite the antibiotic therapy, and her white blood cell count had only a slight improvement, despite the descending CRP. She was then submitted to a bone marrow biopsy.

The results of the study performed were negative for HBV, $\mathrm{HCV}$, HIV, CMV, EBV, brucellosis infections, as well as for the diseases diagnosed by the Venereal Disease Research Laboratory (VDRL) test. The blood culture was negative, but the urine culture was positive for $E$. coli, and the sputum culture was positive for $H$. influenza; these last two cultures were sensitive to $\beta$-lactam antibiotics. The bone marrow biopsy revealed abnormal maturation of the granulocytes, with excessive stage III cells. The parvovirus B19 antibody blood test was positive for immunoglobulin $\mathrm{M}$ (IgM) and immunoglobulin G (IgG) (available only after discharge). The indirect Coombs test confirmed the previous findings (Ccee Kellpositive). The male progenitor was summoned to be tested for Kell antigen, but he never showed up.

Ten days later, the patient demanded to be discharged, against medical advice. The patient was clinically better, asymptomatic and apyretic. The blood tests revealed an improvement in the cell count and inflammatory parameters (Hgb: $9.5 \mathrm{~g} / \mathrm{dL}$, leukocytes: 1,800/uL, neutrophils: 500/uL, 29\%; and CRP: $14.8 \mathrm{mg} / \mathrm{L}$ ) (-Table 1). The obstetric ultrasound revealed that the amniotic fluid was normal, and that the peak systolic velocity of the middle cerebral artery was also normal. The patient was referred to our outpatient clinic to undergo a two-week interval obstetric ultrasound and frequent internal medicine and obstetric surveillance. She only came to one appointment of internal medicine at 22 weeks, 2 of obstetrics at 24 and 28 weeks, and 1 obstetric ultrasound scan at 30 weeks. During all of this period, the patient was asymptomatic, and the entire blood sample tests were normal, except the anti-Kell titters in the indirect Coombs test, which were $1 / 16$ at 23 and 27 weeks. The routine pregnancy serum and urine analyses were normal. The obstetric ultrasound at 30 weeks revealed that there were no morphologic abnormalities: the fetus was in a cephalic presentation, with a growth percentile of 57, deepest fluid pocket of $3.4 \mathrm{~cm}$ (AFI of 11.5), and normal blood flow parameters at the umbilical and middle cerebral arteries. The

Table 1 Evolution of maternal serum analysis results throughout pregnancy

\begin{tabular}{|l|l|l|l|l|l|l|l|l|l|}
\hline & $\begin{array}{l}\text { 19w4d } \\
\text { (Admission) }\end{array}$ & 19w6d & 20w0d & 20w3d & 20w5d & $\begin{array}{l}\text { 21w0d } \\
\text { (Discharge) }\end{array}$ & 23w3d & 27w5d & $\begin{array}{l}\text { 37w5d } \\
\text { (Labor) }\end{array}$ \\
\hline Hemoglobin (g/dL) & 9.1 & 10.4 & 8.5 & 9.6 & 10.0 & 9.5 & 10.0 & 10.5 & 10.4 \\
\hline Hematocrit (\%) & 27 & 32.1 & 25.7 & 29.1 & 29.9 & 28.6 & 29.9 & 32.3 & 33.1 \\
\hline Leukocytes $\left(\mathrm{x} 10^{3} / \mathrm{uL}\right)$ & 1.7 & 2.1 & 2.2 & 1.9 & 1.9 & 1.8 & 3.0 & 6.0 & 6.5 \\
\hline $\begin{array}{l}\text { Neutrophils }\left(\mathrm{x} 10^{3} / \mathrm{uL}\right) \\
{[\%]}\end{array}$ & $\begin{array}{l}0.2 \\
{[14]}\end{array}$ & $\begin{array}{l}0.4 \\
{[17]}\end{array}$ & $\begin{array}{l}0.4 \\
{[19]}\end{array}$ & $\begin{array}{l}0.4 \\
{[23]}\end{array}$ & $\begin{array}{l}0.4 \\
{[19]}\end{array}$ & $\begin{array}{l}0.5 \\
{[29]}\end{array}$ & $\begin{array}{l}1.5 \\
{[51]}\end{array}$ & $\begin{array}{l}4.5 \\
{[75]}\end{array}$ & $\begin{array}{l}4.6 \\
{[70.2]}\end{array}$ \\
\hline Platelets $\left(\mathrm{x} 10^{3} / \mathrm{uL}\right)$ & 249 & 269 & 256 & 274 & 263 & 252 & 254 & 225 & 205 \\
\hline $\begin{array}{l}\text { C-reactive protein } \\
\text { (mg/L) }\end{array}$ & 163 & 147 & 84 & 23 & 14.1 & 14.8 & - & - & 14.5 \\
\hline $\begin{array}{l}\text { Indirect Coombs test } \\
\text { (titter) }\end{array}$ & & $\begin{array}{l}\text { Anti-Kell } \\
(1 / 32)\end{array}$ & & & & & $\begin{array}{l}\text { Anti-Kell } \\
(1 / 16)\end{array}$ & $\begin{array}{l}\text { Anti-Kell } \\
(1 / 16)\end{array}$ & Negative \\
\hline
\end{tabular}


fetal echocardiography was also normal. From then on, the patient missed all of the medical appointments.

At 37 weeks and 4 days of gestation, the patient was readmitted to our hospital with premature rupture of membranes. Upon admission and postpartum, the blood cell count was normal, and the indirect Coombs test result was negative. She had an uncomplicated vaginal delivery. The female newborn weighed 2,780 $\mathrm{g}$ at birth, with Apgar scores of 9 and 10 at the 1st and 5th minutes of life respectively, with no visible abnormalities, and the first days of life examinations were normal, with the newborn requiring no special medical intervention. The analysis of the newborn at birth revealed normal levels of leucocytes $\left(20.6 \times 10^{3} / \mathrm{uL}\right.$ [normal range: 5-21]); normal total and direct bilirubin; and negative CRP. The patient was Kell-negative, and the direct Coombs test was negative as well. Both mother and child were discharged 48 hours after the delivery, according to hospital protocol. The patient never returned to the scheduled medical appointments since then, so we lost track of her and her child.

\section{Discussion}

Pregnancy is a well-known physiological state of immunosuppression. This fact allows the pregnant woman to tolerate antigens in her own body that otherwise would be strange to her immune system, thus avoiding the rejection of fetal antigens. On the other hand, as a consequence, pregnant women are more prone to infectious diseases. The result may only be asymptomatic colonization by microorganisms, and the most common types of colonization are vaginal candidosis and asymptomatic bacteriuria, but they may also result in severe infections, such as septicemia of various origins. Some infections may endanger the health of the mother, of the fetus, or of both of them. Our patient presented with persistent hyperthermia, with no other symptoms or physical findings suggesting any infectious origin. The blood study upon admission revealed iron deficiency anemia (which is common among pregnant women), leukopenia with neutropenia, and elevated CRP, so the patient was admitted to our inpatient ward with the diagnosis of febrile neutropenia, in isolation, and was medicated with a broad spectrum antibiotic (imipenem). Blood, Urine and sputum specimens were collected to search for points of infection. Serum analyses were preformed to exclude all major causes of hyperthermia and/or neutropenia. As initially there was no clinical improvement and there was still no explanation for the facts, a bone marrow biopsy was performed.

The studied revealed $H$. influenza in the sputum, and $E$. coli in the urine. Both agents were sensitive to imipenem. This could be part of the explanation for the febrile condition, but it wouldn't explain the neutropenia.

Blood tests revealed seroconversion to parvovirus B19 (IgG and IgM positive). Parvovirus B19 is the cause of infectious erythema. The patient had no cutaneous signs, but, in adults, this disease may have milder presentations. Hyperthermia is one of the other signs of parvovirosis. The patient also reported having contact with her nephew, who had chickenpox 3 weeks before, but the child had not been examined by a doctor, and there were no clinical data confirming this infection, so it is possible that he had a "slapped cheek" erythema caused by parvovirus B19, and infected his aunt afterwards. Parvovirus B19 has tropism for erythrocytes, and aplasia of the red line is common, especially in groups already suffering from anemia, including iron deficiency anemia, which was the case of our patient. However, there are few reports of bicytopenia or pancytopenia caused by parvovirus. Our patient had leukopenia with neutropenia, which (although rare) has already been described in the literature in healthy adults. There is a possibility that this immunosuppression, along with the pregnancy, may have led to the respiratory and urinary infections.

Parvovirus B19 is also a well-known potentially teratogenic infection, especially if acquired before 20 weeks of gestation. Our patient was in a limit age, considering this cutoff point, when the infection was acquired. Due to lack of compliance, the patient was only submitted to 2 obstetric ultrasounds, at 19 and 30 weeks, and none of them revealed fetal malformations, amniotic fluid changes, or signs of anemia, including middle cerebral artery systolic peak velocity. The Coombs test was only negative at delivery, but, as a serologic reaction, the result may remain positive for weeks after exposure to the antigen.

We had no opportunity to type the male progenitor for Kell, which would rule out the possibility of immune reaction if the father was negative. We opted not to type the fetus because there was no evidence of fetal anemia and so we could avoid an invasive procedure.

Unfortunately, it was not possible to correctly follow-up our patient and her child due to lack of compliance to the medical appointments, but, according to the facts we have, the pregnancy and the well-being of the mother and the fetus were not affected by these events. In the end, the newborn was Kell-negative, so the only explanation we have for the positive indirect Coombs test result is the urine colonization by E. coli, which, according to the literature, may explain the transient positive Coombs test.

\section{Conclusion}

Pregnancy is a physiological state of immunosuppression that may lead to atypical manifestations of different infectious diseases. Parvovirus B19 is a potentially teratogenic infection, but the possible harm to the mother must never be neglected. It has tropism for red line blood cells, but, in rare cases, it may affect the white line instead, which may be serious in immune-compromised groups such as pregnant women. Some infectious agents such as E. coli may be a cause of cross reaction to fetal blood antigens such as the Kell antigen, resulting in a false-positive indirect Coombs test.

Conflicts of Interest

The authors have no conflicts of interest to report. 


\section{References}

1 Neu N, Duchon J, Zachariah P. TORCH infections. Clin Perinatol 2015;42(01):77-103, viii

2 Feldman DM, Keller R, Borgida AF. Toxoplasmosis, parvovirus, and cytomegalovirus in pregnancy. Clin Lab Med 2016;36(02): 407-419. Doi: 10.1016/j.cll.2016.01.011

3 Sampedro Martínez A, Martínez LA, Teatino PM, RodríguezGranger J. Diagnóstico de infección congénita. Enferm Infecc Microbiol Clin 2011;29(Suppl 5):15-20. Doi: 10.1016/S0213005X(11)70039-8

4 Mustafa MM, McClain KL. Diverse hematologic effects of parvovirus B19 infection. Pediatr Clin North Am 1996;43(03):809-821. Doi: 10.1016/S0031-3955(05)70434-X

5 Kawakami C, Kono Y, Inoue A, Takitani K, Ikemoto T, Tamai H. Severe bone marrow failure associated with human parvovirus B19 infection in a case with no underlying disorder. Int J Hematol 2012;96(06):820-821. Doi: 10.1007/s12185-012-1214-7

6 Barlow GD, McKendrick MW. Parvovirus B19 causing leucopenia and neutropenia in a healthy adult. J Infect 2000;40(02):192-195. Doi: 10.1016/S0163-4453(00)80018-3

7 Tolfvenstam T, Broliden K. Parvovirus B19 infection. Semin Fetal Neonatal Med 2009;14(04):218-221. Doi: 10.1016/j.siny.2009.01.007
8 Giorgio E, De Oronzo MA, Iozza I, et al. Parvovirus B19 during pregnancy: a review. J Prenat Med 2010;4(04):63-66https:// www.ncbi.nlm.nih.gov/pmc/articles/PMC3279187/ AccessedAugust302016

9 Haun L, Kwan N, Hollier LM. Viral infections in pregnancy. Minerva Ginecol 2007;59(02):159-174

10 Bonvicini F, Bua G, Gallinella G. Parvovirus B19 infection in pregnancy-awareness and opportunities. Curr Opin Virol 2017; 27:8-14. Doi: 10.1016/j.coviro.2017.10.003

11 Soma-Pillay P, Nelson-Piercy C, Tolppanen H, Mebazaa A. Physiological changes in pregnancy. Cardiovasc J Afr 2016;27(02): 89-94. Doi: 10.5830/CVJA-2016-021

12 Egbor M, Knott P, Bhide A. Red-cell and platelet alloimmunisation in pregnancy. Best Pract Res Clin Obstet Gynaecol 2012;26(01): 119-132. Doi: 10.1016/j.bpobgyn.2011.10.004

13 Savalonis JM, Kalish RI, Cummings EA, Ryan RW, Aloisi R. Kell blood group activity of gram-negative bacteria. Transfusion 1988; 28(03):229-232. Doi: 10.1046/j.1537-2995.1988.28388219149.x

14 Marsh WL, Nichols ME, Oyen R, et al. Naturally occurring anti-Kell stimulated by $\mathrm{E}$. coli enterocolitis in a 20-day-old child. Transfusion 1978;18(02):149-154. Doi: 10.1046/j.15372995.1978.18278160576.x 